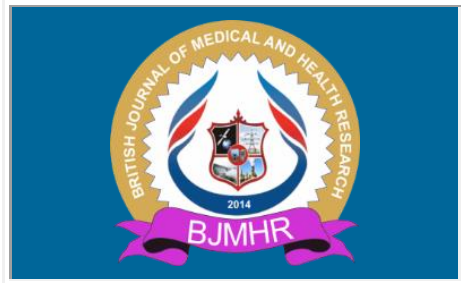

\title{
BJMHR
}

British Journal of Medical and Health Research

Journal home page: www.bjmhr.com

\section{Prevalence of Anameia and malnutrition among hospitalized patients attending Al-Nasser paediatric hospital, Gaza, Palestine}

\author{
May Hamouda* \\ Medical laboratory Sciences Department, Faculty of Health Sciences, Islamic University of \\ Gaza, P.O.Box. 108, Gaza, Palestine
}

\section{ABSTRACT}

The present study aimed to determine the prevalence of anaemia and malnutrition and some risk factors among hospitalized children attending Al-Nasser paediatric hospital. A crosssectional study among hospitalized children attending Al-Nasser paediatrics hospital. The study included 522 children during the period May 2002 to May 2003. Data collection was through blood specimens, anthropometric indices and the questionnaire. The present study included 522 children attending AL-Nasser Paediatric Hospital with 334 males (64.0\%) and 188 females (36.0\%). Those children are distributed into three regions; the city $316(60.5 \%)$, the camp $181(34.7 \%)$ and village $25(4.8 \%)$. The present study showed that $326(62.5 \%)$ were anaemic, while 220/522 (42.1\%) were underweight, stunting were 172/522 (32.9\%) and wasting 140/522 (26.8\%). The present study indicated that underweight and wasting were lower among males (38.6\%), (20.0\%) compared to females $(48.4 \%)$, (38.8\%) with a significance level $(\mathrm{p}=0.02, \mathrm{p}=0.001)$. Palestinian children at high risk of anaemia and malnutrition. These two conditions should be considered by health authorities and urgent need for immediate intervention should be taken to minimize the consequences.

Keywords: Anemia, Malnutrition, Prevalence, Gaza, Children 


\section{INTRODUCTION}

Iron deficiency anaemia is a decrease in the total hemoglobin levels caused by a lack of sufficient iron. It is the most common cause of anaemia worldwide. Iron is needed to form haemoglobin and is mostly stored in the body in the form of ferritin and hemosiderin ${ }^{1}$. Anaemia is a serious global public health problem that particularly affects young children and pregnant women. WHO estimates that $42 \%$ of children less than 5 years of age and $40 \%$ of pregnant women worldwide are anaemic ${ }^{2}$.In developing countries, low standards of living, low socioeconomic conditions, restricted access to food and lack of knowledge for good dietary practices and personal hygiene contribute even more to a high occurrence of iron deficiency and hence anemia $^{3}$. Intestinal parasitic infection, due to poor hygienic conditions also interferes with iron absorption, thus expanding the prevalence of iron deficiency anaemia in the developing world ${ }^{4}$. The prevalence of anaemia is estimated at $9 \%$ in countries with high development, in countries with low development the prevalence is $43 \% 5$.

The literature on anaemia and malnutrition from Palestine and neighbouring countries are presented in table 1. 
Table 1: Literature on anaemia and malnutrition from Palestine and neighbouring countries

\begin{tabular}{|c|c|c|c|c|c|}
\hline Country & $\begin{array}{l}\text { Authors, } \\
\text { years }\end{array}$ & Methodology & $\%$ & Target/Sample & $\begin{array}{l}\text { Disease/ } \\
\text { condition }\end{array}$ \\
\hline $\begin{array}{l}\text { Palestine (Gaza } \\
\text { Strip) }\end{array}$ & 6 & $\begin{array}{l}\text { A descriptive cross- } \\
\text { sectional }\end{array}$ & $40.7 \%, 9.1 \%$ & preschool children & Anaemia, Stunting \\
\hline Jordan & 7 & $\begin{array}{l}\text { A national population- } \\
\text { based household }\end{array}$ & $4.9 \%, 19.3 \% 27.4 \%$ & $\begin{array}{l}\text { Males, non-pregnant females and } \\
\text { pregnant femeles }\end{array}$ & Anaemia \\
\hline $\begin{array}{l}\text { Refugee camps } \\
\text { outside Palestine }\end{array}$ & 8 & A cross-sectional study & $\begin{array}{l}\text { (Gaza, 29.3\%; West Bank, 22.0\%; } \\
\text { Syria, 30.0\%; and Lebanon, } 18.3 \% \text { ) }\end{array}$ & $\begin{array}{l}\text { UNRWA schools in Gaza, West } \\
\text { Bank, Syria, and Lebanon in } 2017\end{array}$ & Anaemia \\
\hline Tanzania & 9 & $\begin{array}{l}\text { Random sampling } \\
\text { technique }\end{array}$ & $84.6 \%$ & $\begin{array}{l}436 \text { children aged 6-59 months } \\
\text { in Arusha District }\end{array}$ & Anaemia \\
\hline $\begin{array}{l}\text { Baghdad City, } \\
\text { Iraq }\end{array}$ & 10 & A cross-sectional Study & $18.2 \%$. & 3 to 5 Years Old Children & $\begin{array}{l}\text { Malnutrition } \\
\text { (Underweight) }\end{array}$ \\
\hline $\begin{array}{l}\text { Palestine } \\
\text { (Gaza Strip) }\end{array}$ & 11 & A cross-sectional Study & $33.5 \%$ & $\begin{array}{l}\text { kindergarten children } \\
\text { (marginalized areas of the Gaza) }\end{array}$ & Anaemia \\
\hline $\begin{array}{l}\text { Palestine } \\
\text { (West Bank) }\end{array}$ & 12 & MoH Annual report & $38.5 \%$ & Children at age 12 month & Anaemia \\
\hline $\begin{array}{l}\text { Palestine } \\
\text { (Gaza Strip) }\end{array}$ & 13 & $\begin{array}{l}\text { Retrospective cohort } \\
\text { study }\end{array}$ & & children under 2 years & Stunting \\
\hline Egypt & 14 & A cross-sectional Study & $39.6 \%$ & preschool children & Anaemia \\
\hline $\begin{array}{l}\text { Palestine } \\
\text { (West Bank) }\end{array}$ & 16 & In a national study & $37.9 \%$ & pre-school children & Anaemia \\
\hline Palestine & 17 & $\begin{array}{l}\text { Retrospective cohort } \\
\text { study }\end{array}$ & $\begin{array}{l}39.5 \% \text { IDA, } 2.9 \% \text { wasting, } 4.7 \% \\
\text { underweight and } 10.9 \% \text { stunted }\end{array}$ & $\begin{array}{l}\text { Palestinian preschool children } \\
\text { during the period 1998-2007 }\end{array}$ & $\begin{array}{l}\text { silent epidemic of } \\
\text { malnutrition }\end{array}$ \\
\hline $\begin{array}{l}\text { Palestine } \\
\text { (Gaza Strip) }\end{array}$ & 18 & A cross-sectional study & $\begin{array}{l}59.7 \%, 46.5 \% \text { and } 13.5 \% \text { of which } \\
\text { are mild and moderate, respectively }\end{array}$ & preschool children & Anaemia \\
\hline
\end{tabular}


The present study was undertaken to identify the prevalence of anaemia, malnutrition among hospitalized children attending Al-Nasser Paediatrics Hospital as well as the association between anaemia and malnutrition.

\section{MATERIALS AND METHOD}

\section{Ethical considerations}

Ethical approval was obtained from the Ministry of Health dated 2003. All children investigated were in accompanied with one of their parents and informed consent was filled by each sponsor after verbal explanation about the purpose of the study.

\section{Sample selection}

The information of 522 hospitalized children attending Al-Nasser Paediatric Hospital were obtained and permitted from ${ }^{19}$ study.

\section{Data collection}

The study was during the period May 2002 to May 2003, where data collection included the collection of blood specimens, anthropometric indices and a questionnaire including; age, sex, residency, father education, and father occupation.

\section{Measurement of Health Status}

\section{Blood specimen collection and analysis}

After obtaining the parents consent, three $\mathrm{ml}$ of venous blood was drawn into an EDTA container for a complete blood count (C.B.C), to measure haemoglobin (Hb) suing the CellDYN 1700 in the Hospital laboratory.

\section{Haematological criteria for anaemia}

Each child was considered anaemic when the haemoglobin level was lower than $11 \mathrm{gm} / \mathrm{dl}$ by estimating haemoglobin mean ${ }^{20}$.

\section{Anthropometric measurements for Physical growth}

\section{Body weight}

The weight of the child was measured by using Health Meter (Capacity $136 \mathrm{Kg}$, UK), set on a constant platform with the initial point on the scale exactly at zero; each weight was taken to the nearest $0.5 \mathrm{Kg}$. With each child was standing on the balance and the observer recorded the reading of the weight. The average of two readings was taken for each child.

\section{Body height}

The measurement of height was made when a child was in full extension, standing on the platform of the balance, and the movable scaled meter extended and slides from a fixed position up to reach the head. Height was measured to the nearest $1.0 \mathrm{~cm}$. These measurements were made with the children without shoes and accuracy was assured by taking an average of two readings. 


\section{Interpretation of height and weight}

Weight for age, (W/A) defines the general nutritional status, weight for height, (W/H) means wasting, and height for age, (H/A) means stunting, have been recommended for use as indicators of nutritional status of children. These indicators were expressed as percentages of the reference values (percentiles) for weight, height and age using Cole's Growth Assessment Slide Rule. The Gomez classification for W/A and Water low classification for W/H and H/A were applied $^{21}$.

\section{Statistical analysis of data}

Data was computer analyzed using SPSS/PC (Statistical Package for the Social Sciences Inc, Chicago, Illinois $)^{22}$. Simple distribution of the study variables, cross-tabulation and Chi-square tests were used to identify the significance of the relationships (associations and interactions) among the dependent variables, blood indices and physical growth. The independent variables included the general rate of anaemia, age, sex, residence, father occupation.

\section{RESULTS AND DISCUSSION}

The present study included 522 children attending AL-Nasser Paediatric Hospital with 334 males (64.0\%) and 188 females (36.0\%). Those children are distributed into three regions; the city $316(60.5 \%)$, the camp 181 (34.7\%) and village 25 (4.8\%). The present study showed that $326(62.5 \%)$ were anaemic, while 220/522 (42.1\%) were underweight, stunting were 172/522 (32.9\%) and wasting 140/522 (26.8\%). The sociodemographic characters are represented in Table 2.

The present study indicated that males were found to be more anaemic $66.5 \%$ than females $55.9 \%$ with a significance difference $(\mathrm{p}=0.001)$. The rate of anaemia among children in the age categories tend to decrease with increasing age with a significance level $(\mathrm{p}=0.001)$. Anaemia was high among children who are residing in the city $65.2 \%$. Out-patients were found to be less anaemic than in-patients with a significance level $(\mathrm{p}=0.001)$. Anaemia was high $66.5 \%$ among children belong to fathers with secondary education. Children belongs to un-employed fathers had high rate of anaemia $64.9 \%$. Children who are drinking tea had lower anaemia $40.1 \%$ than who do not $59.9 \%$ with a significance level $(\mathrm{p}=0.001)$ Table 3 .

Table 2: Anaemic and non-anaemic children with relation to sociodemographic charterers

\begin{tabular}{|c|c|c|c|}
\hline \multirow[t]{2}{*}{ Variable } & Anaemic & Not-anaemic & \multirow[t]{2}{*}{$\left(\chi^{2}, p\right.$-value $)$} \\
\hline & No. $\quad(\%)$ & No. $\quad(\%)$ & \\
\hline \multicolumn{4}{|l|}{ Sex } \\
\hline Males $(n=334)$ & $222(66.5)$ & $112(33.5)$ & $(5.79,0.001)^{*}$ \\
\hline Females $(n=188)$ & $105(55.9)$ & $83(44.1)$ & \\
\hline \multicolumn{4}{|l|}{ Age } \\
\hline$<1$ year & $154(76.3)$ & $48(23.7)$ & \\
\hline $1-4$ year $(n=224)$ & $140(62.5)$ & $84(37.5)$ & $(21.40,0.001)^{*}$ \\
\hline
\end{tabular}




\begin{tabular}{llll}
\hline 5-8 year $(\mathrm{n}=64)$ & $22(34.4)$ & $42(65.6)$ & \\
9-12 year $(\mathrm{n}=32)$ & $11(34.4)$ & $21(65.6)$ & \\
$\begin{array}{l}\text { Residency } \\
\text { City }(\mathrm{n}=316)\end{array}$ & $206(65.2)$ & $110(34.8)$ & \\
Camp $(\mathrm{n}=181)$ & $108(59.7)$ & $73(40.3)$ & $(2.77,0.250)$ \\
$\begin{array}{l}\text { Village }(\mathrm{n}=25) \\
\text { Patient classification }\end{array}$ & $13(52.0)$ & $12(48.0)$ & \\
Out-patient $(\mathrm{n}=187)$ & $105(56.1)$ & $821(43.9)$ & \\
In-patient $(\mathrm{n}=335)$ & $222(66.3)$ & $113(33.7)$ & $(5.25,0.001)^{*}$ \\
Father education & & & \\
Primary education $(\mathrm{n}=106)$ & $64(60.4)$ & $42(39.6)$ & \\
$\begin{array}{l}\text { Prepatory education }(\mathrm{n}=124) \\
\text { Secondary education }(\mathrm{n}=173)\end{array}$ & $81(65.3)$ & $43(34.7)$ & $(3.74,0.291)$ \\
Higher education $(\mathrm{n}=119)$ & $67(56.3)$ & $58(33.5)$ & \\
Father occupation & & & \\
Employed $(\mathrm{n}=146)$ & $90(61.6)$ & $56(38.4)$ & \\
Laborer $(\mathrm{n}=302)$ & $189(62.6)$ & $113(37.4)$ & $(0.21,0.896)$ \\
Un-employed $(\mathrm{n}=74)$ & $48(64.9)$ & $26(35.1)$ & \\
\hline 05 is significant & & & \\
\hline
\end{tabular}

$* p<=0.05$ is significant

The present study indicated that underweight and wasting were lower among males $(38.6 \%)$, (20.0\%) compared to females $(48.4 \%),(38.8 \%)$ with a significance level $(\mathrm{p}=0.02, \mathrm{p}=0.001)$. While stunting was higher among males $37.4 \%$ compared to females $25.0 \%$ ( $\mathrm{p}=0.003$ ). Underweight, stunting and wasting were found to be high among children aged from 5-8 months, $58.1 \%, 47.2 \%$ and $40.5 \%$ with a significance level. While children aged <1y years had high rates of anthropometric deficiencies. Similar rate $(48.0 \%)$ of underweight, stunting and wasting was found among children who are residing in the village and higher than who are residing in the city and the refugee camp with a significance level. Lower rate of underweight and stunting were noticed among children whom belong to fathers of high education Table 3 .

Table 3: underweight, stunting and wasting among children with relation to different variables

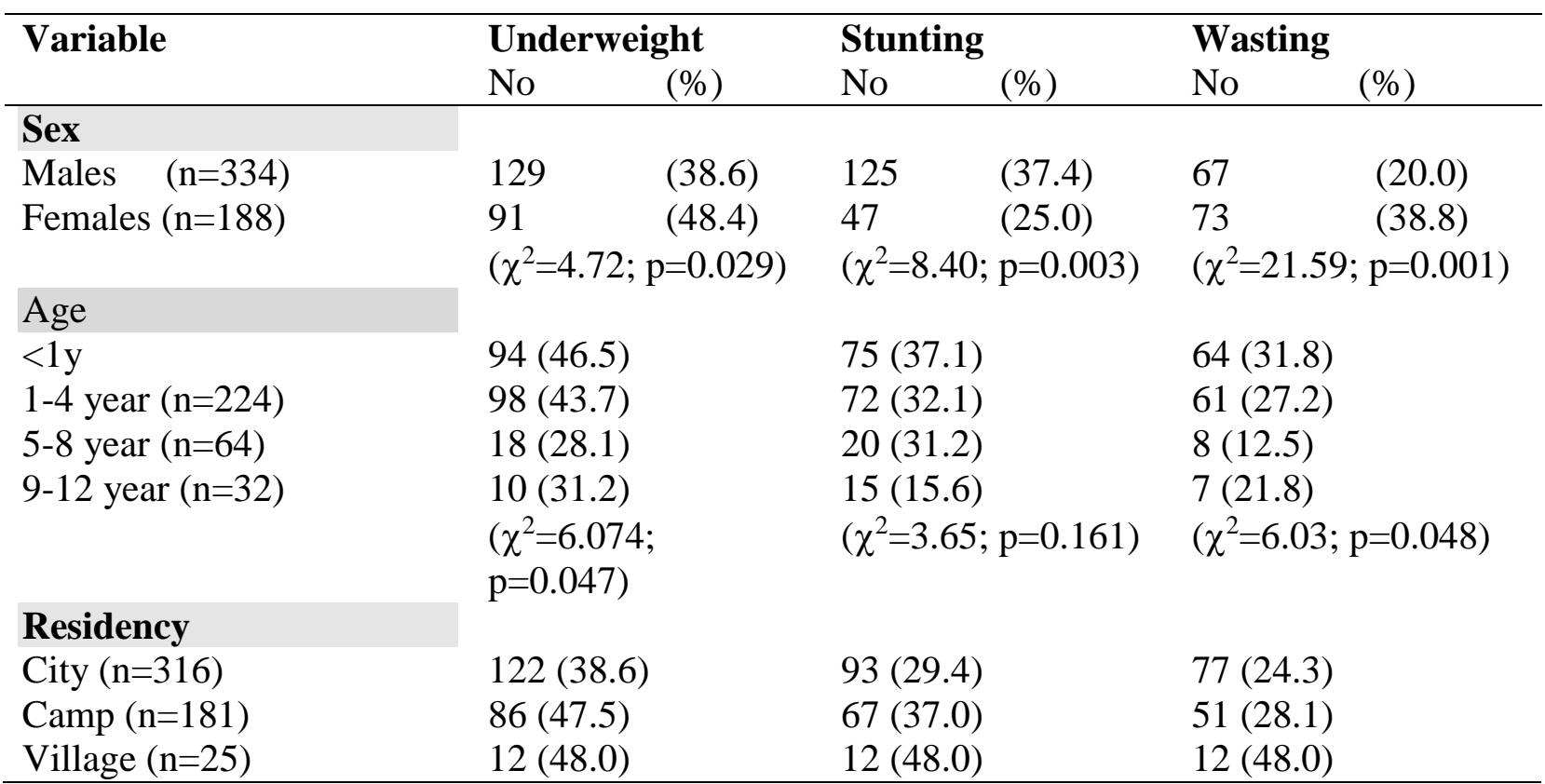




\section{Father education}

Primary education $(n=106)$

Prepatory education

$(\mathrm{n}=124)$

Secondary education

$(\mathrm{n}=173)$

Higher education $(n=119)$

\section{Father occupation}

Employed $(\mathrm{n}=146)$

Laborer $(n=302)$

Un-employed $(\mathrm{n}=74)$ $\left(\chi^{2}=4.11 ; p=0.127\right) \quad\left(\chi^{2}=5.69 ; p=0.058\right) \quad\left(\chi^{2}=6.85 ; p=0.032\right)$

$\begin{array}{lll}45(42.4) & 39(36.7) & 27(25.5) \\ 55(44.3) & 46(37.1) & 27(21.7) \\ 82(47.3) & 54(31.2) & 55(31.8) \\ 38(31.9) & 33(27.7) & 31(26.1)\end{array}$

$\left(\chi^{2}=7.30 ; \mathrm{p}=0.062\right) \quad\left(\chi^{2}=3.37 ; \mathrm{p}=0.337\right) \quad\left(\chi^{2}=3.66 ; \mathrm{p}=0.300\right)$

\begin{tabular}{lll}
$55(37.7)$ & $55(37.7)$ & $39(26.7)$ \\
$132(43.7)$ & $96(31.8)$ & $76(25.2)$ \\
$33(44.6)$ & $21(28.4)$ & $25(33.8)$ \\
$\left(\chi^{2}=1.68 ; \mathrm{p}=0.431\right)$ & $\left(\chi^{2}=2.35 ; \mathrm{p}=0.307\right)$ & $\left(\chi^{2}=2.25 ; \mathrm{p}=0.324\right)$ \\
\hline
\end{tabular}

Children of employed fathers had lower rates of underweight while stunting was lower among children belongs to un-employed father. Wasting was lower among children belong to labourer fathers. Underweight of $3^{\text {rd }}$ degree was found lower among anaemic and non-anaemic children. Severe stunting was similar among anaemic and non-anaemic children $6.4 \%$ and $6.2 \%$. Severe wasting was lower among among anaemic children $3.1 \%$ compared to non-anaemic children $4.1 \%$ Table 4.

Table 4: Underweight, stunting and wasting among children with relation to anaemia

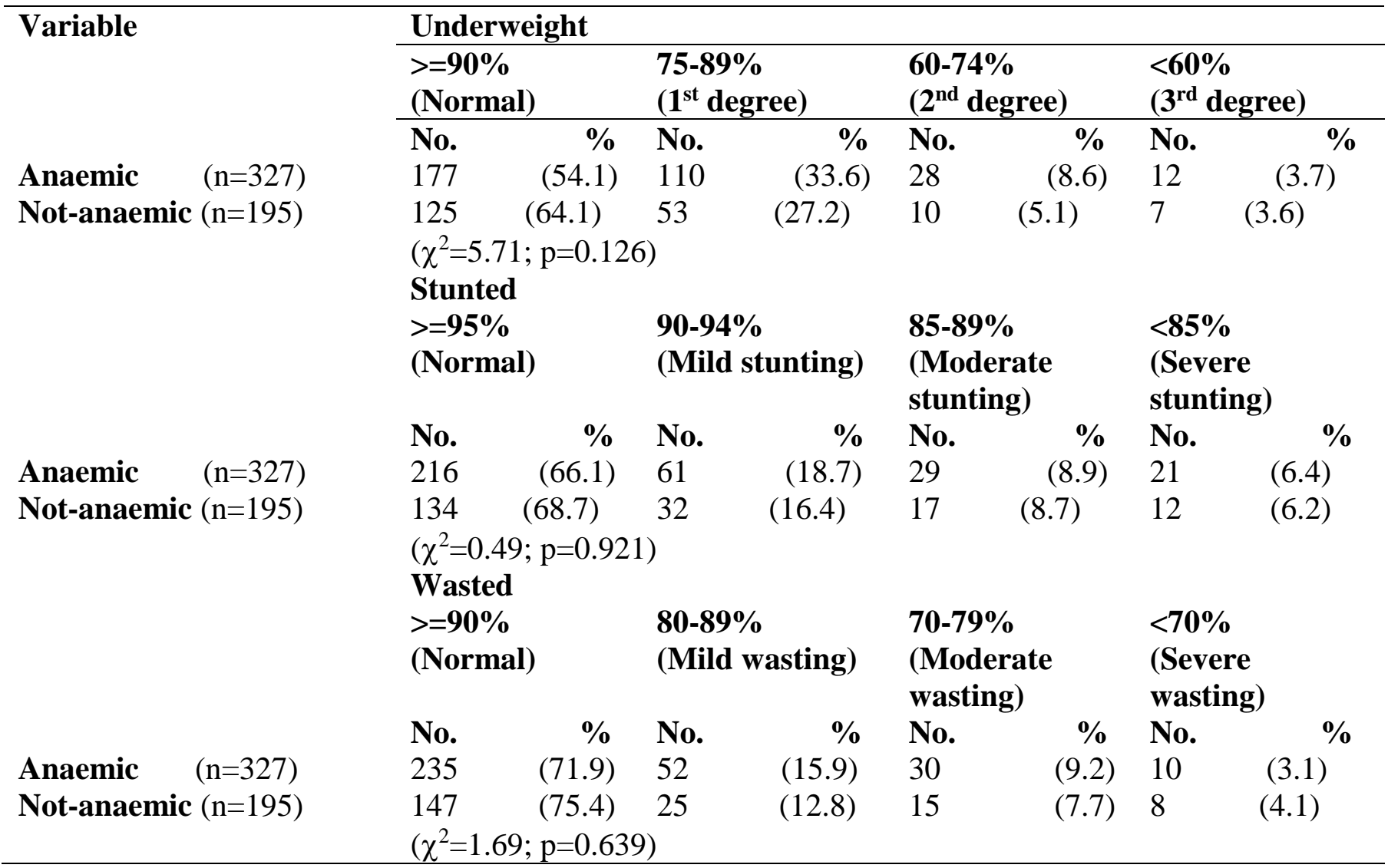

The findings of the present study showed that the prevalence of anaemia among children was high $(62.5 \%)$ compared to other regions of Palestine. Our findings for the prevalence of 
underweight $(42.1 \%)$, stunting (32.9\%) and wasting (26.8\%) were different to that reported $b^{23}$ in the same area and may reflect increasing of underweight. Where their study showed that the prevalence of anemia among 102 children attending the main four primary health care centers in Gaza Strip was $72.8 \%$. Anthropometrical indices showed that the prevalence of wasting, stunting, underweight were $34.3 \%, 31.4 \%, 31.45 \%$ respectively.

Where a study among pre-school children 6-59 months indicated that anaemia was $37.9 \%$ in the West Bank ${ }^{16}$. Through evaluation project's impact they performed two random surveys in West Bank: one before and one after the project. Before the project $30.1 \%$ of children (CI $95 \%$ $=24.5-35.6 \%)$ were found anaemic $(<11 \mathrm{~g} / \mathrm{dl})$, while after the prevalence was $18.8 \%$ (CI 95\% $=14.8-22.8 \%$; decrease of $38 \%, p=0.001)^{24}$. In rural Wardha, central India the prevalence of nutritional anaemia was $80.3 \%$ among children aged 6-35 months ${ }^{25}$.

Our results regarding the prevalence of anaemia and sex are different from that reported by ${ }^{26}$ where he reported that the prevalence of anaemia was high among females.

In the present study there was evident that the prevalence of anaemia decreasing with increasing age and these results were consistent with that reported $b y^{27}$.

The prevalence of iron deficiency, and IDA among females students between the ages of 6 to 12 years old were randomly selected from a governmental school in northern Jeddah was $25.2 \%$ and $10.6 \%$, respectively. At the same time, underweight affected $14.2 \%$ of the students, and stunting affected $12.2 \%$. Moreover, $9.8 \%$ of the students were obese and $13.8 \%$ suffered from wasting $^{28}$.

The prevalence of anaemia was high among children who are coming from the city compared to the camp and the village; these un-explained findings may need further and future study. While there was a statistical significance in the prevalence of stunting $(\mathrm{p}=0.058)$ and wasting $(\mathrm{p}=0.032)$ regarding residency where increasing was noticed in the camp and village as indicated in table 2 . This may be attributed to less availability of food in both camp and village. The education and occupation of the father did not make a big variation in the prevalence of anaemia and anthropometric indices. The high prevalence of anemia and anthropometric indices in the present study may be contributed to high poverty rates which led to increased food insecurity based on limited access to food due to curfews and closures, as well as high unemployment, depletion of resources. According to World Food programme (WFP) 38\% of the occupied Palestinian territory population were food insecure ${ }^{29}$. The study showed that $33.6 \%$ of $1^{\text {st }}$ degree underweight was anaemic where $2^{\text {nd }}$ and $3^{\text {rd }}$ degree of underweight tends to decrease among anemic children the same findings for stunting and wasting. So children under the study are at high risk for anaemia and malnutrition due to many reasons; insecurity of food, quality and health food, unemployment, closure and siege on Palestinian territories. 


\section{CONCLUSION}

Palestinian children at high risk of anaemia and malnutrition. These two conditions should be considered by health authorities and urgent need for immediate intervention should be taken to minimize the consequences.

\section{ACKNOWLEDGEMENTS}

The author would like to thank all children and their families who are kindly participated in the study. Also, many thanks to the Ministry of Health for facilitating and approval of the study.

\section{REFERENCES}

1. Goldenring J. Iron deficiency anemia- children. Medline plus Journal. 2003;56(6):1526.

2. WHO. Anaemia, https://www.who.int/health-topics/anaemia\#tab=tab_1 accessed 3-62020; 2020.

3. Soekarjo DD, de Pee S, Bloem MW, Tjiong R, Yip R, Schreurs WH, et al. Socioeconomic status and puberty are the main factors determining anaemia in adolescent girls and boys in East Java, Indonesia. Eur J Clin Nutr. 2001;55(11):932-9.

4. Musaiger A. Iron Deficiency Anaemia Among Children and Pregnant Women in the Arab Gulf Countries: The Need for Action. Nutr Health. 2002;16(3):161-71. .

5. McLean E, Cogswell M, Egli I, Wojdyla D, de Benoist B. Worldwide prevalence of anaemia, WHO Vitamin and Mineral Nutrition Information System, 1993-2005. Public Health Nutr. 2009;12(4):444-54.

6. Marwan Jalambo BK, Mueen Kareri, Samaher Younis, Sujod Aljazzar. Prevalence of Anemia, Stunting and Parasitic Infection Among 5-6 Years Children in Gaza Strip, Palestine. Public Health and Preventive Medicine. 2020;5(1):6-15.

7. Abdo N, Douglas S, Batieha A, Khader Y, Jaddou H, Al-Khatib Sea. The prevalence and determinants of anaemia in Jordan. East Mediterr Health J 2019;25(5):341-9 .

8. Abu Kishk N, Hababeh M, Saleh S, Turki Y, Khiteb Z, Kassim N, et al. Prevalence of anaemia in children newly registered at UNRWA schools: a cross-sectional study. The Lancet. 2019;393(S35).

9. Kejo D, Petrucka PM, Martin H, Kimanya ME, Mosha TC. Prevalence and predictors of anemia among children under 5 years of age in Arusha District, Tanzania. Pediatric Health Med Ther. 2018;9:9-15.

10. Ghazi HF, Mustafa J, Aljunid S, Isa Z, Abdalqader MA. Malnutrition among 3 to 5 years old children in Baghdad city, Iraq: a cross-sectional study. J Health Popul Nutr. 2013;31(3):350-5. 
11. Sirdah MM, Yaghi A, Yaghi AR. Iron deficiency anemia among kindergarten children living in the marginalized areas of Gaza Strip, Palestine. Rev Bras Hematol Hemoter. 2014;36(2):132-8.

12. MoH. Health Annual Report, Ministry of Health, .Palestine 2018.: Ministry of Health; 2019.

13. Albelbeisi A, Shariff ZM, Mun CY, Abdul-Rahman H, Abed Y. Growth patterns of Palestinian children from birth to 24 months. East Mediterr Health J. 2018;24(3):30210.

14. Megally R, Ghoneim H. Evaluation of health intervention: a case of preschool children in Egypt. . Palgrave communications 2020;6:83.

15. Thorne CJ, Roberts LM, Edwards DR, Haque MS, Cumbassa A, Last AR. Anaemia and malnutrition in children aged 0-59 months on the Bijagos Archipelago, GuineaBissau, West Africa: a cross-sectional, population-based study. Paediatr Int Child Health. 2013;33(3):151-60.

16. Halileh S, Gordon NH. Determinants of anemia in pre-school children in the occupied Palestinian territory. J Trop Pediatr. 2006;52(1):12-8.

17. Tsigga M, Grammatikopoulou MG. Assessing the silent epidemic of malnutrition in Palestinian preschool children. J Epidemiol Glob Health. 2012;2(4):181-91.

18. El Kishawi R, Soo K, Abed Y, Wan Muda W. Anemia among children aged 2-5 years in the Gaza Strip- Palestinian: a cross sectional study. BMC Public Health. 2015;15.

19. Al-Hindi AI. Diagnosis of gastrointestinal parasites among hospitalized patients attending Al-Nasser Paediatric Hospital, Gaza, Palestine. Journal f Public Health. 2009;17:49-53.

20. WHO. Measuring change in nutritional status. Guidelines for assessing the nutritional impact of supplementary feeding programmes for vulnerable groups. 1983 ; World Health Organization, WHO Geneva.; 1983.

21. Ebrahim G. Paediatric practice in developing countries. . . 2nd edition ed: Machmillan Press Ltd 1993.

22. SPSS. Statistical Package for the Social Sciences. (SPSS, Version 8.0). Chicago IL1999 ;USA. . 1999.

23. Radi S, Abu Mourad T, Papandreou C. Nutritional status of Palestinian children attending primary health care centers in Gaza. Indian J Pediatr. 2009;76(2):163-6.

24. Magoni M, Jaber M, Piera R. Fighting anaemia and malnutrition in Hebron (Palestine): impact evaluation of a humanitarian project. Acta Trop. 2008;105(3):242-8. 
25. Sinha N, Deshmukh PR, Garg BS. Epidemiological correlates of nutritional anemia among children (6-35 months) in rural Wardha, Central India. Indian J Med Sci. 2008;62(2):45-54.

26. Bharati P, Ghosh R, Gupta R. Socioeconomic Condition and Anaemia among the Mahishya Population of Southern West Bengal, India. Malays J Nutr. 2004;10(1):2330.

27. Onyemaobi G, Onimawo I. Anaemia Prevalence among under- five Children in Imo State, Nigeria. . Australian J of Basic and Applied Sci. 2011;5(2):122- 6.

28. Gari MA. Prevalence of Iron Deficiency Anemia among Female Elementary School Children in Northern Jeddah, Saudi Arabia Journal of King Abdulaziz University Medical Sciences. 2008;15(1):63-75.

29. WHO. Health conditions in the occupied Palestinian territory, including east Jerusalem, and in the occupied Syrian Golan. Fifty World Health assembly.: World Health Organization; 2006.

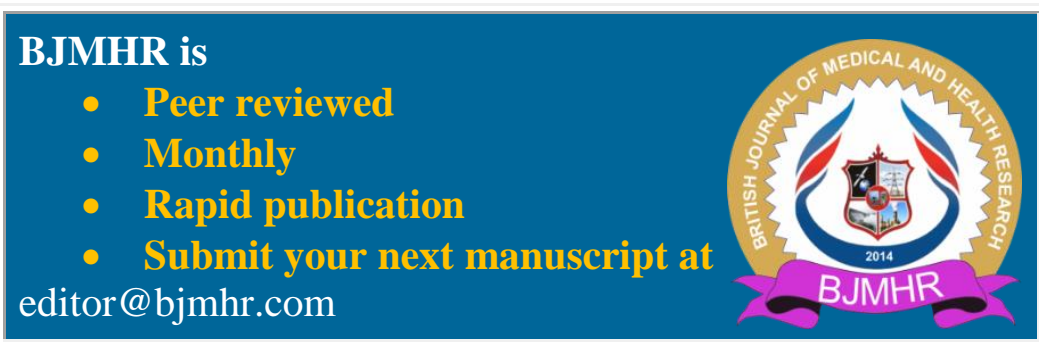

